\title{
Phlebotomines (Diptera, Psychodidae) in the Ribeira Valley Speleological Province - 1. Parque Estadual Intervales, state of São Paulo, Brazil
}

\author{
Eunice Aparecida Bianchi Galati ${ }^{1}$, Ana Maria Marassá2,3, Rute Maria Gonçalves-Andrade ${ }^{4}$, \\ Cleide Aschenbrenner Consales ${ }^{5}$ \& Edna F. M. Bueno ${ }^{1}$
}

${ }^{1}$ Departamento de Epidemiologia, Faculdade de Saúde Pública, Universidade de São Paulo. Av. Dr. Arnaldo 715, 01246-904 São Paulo-SP, Brazil. egalati@ usp.br

${ }_{2}^{2}$ Programa de Pós-Graduação em Saúde Pública, Faculdade de Saúde Pública, Universidade de São Paulo. Av. Dr. Arnaldo 715, $01246-904$ São Paulo-SP, Brazil. anamarassa@usp.br

${ }^{3}$ Secção de Parasitoses Sistêmicas, Instituto Adolpho Lutz, Av. Dr. Arnaldo 355, 01246-904 São Paulo-SP, Brazil.

${ }^{4}$ Laboratório de Imunoquímica, Instituto Butantan, Av. Vital Brasil 1500, 05508-900 São Paulo-SP, Brazil. rutemgdeandrade@butantan.gov.br

${ }^{5}$ Instituto Pasteur, Av. Paulista 393, 01311-000 São Paulo-SP, Brazil. cleide135@yahoo.com.br

\begin{abstract}
Phlebotomines (Diptera, Psychodidae) in the Ribeira Valley Speleological Province - 1. Parque Estadual Intervales (PEI), São Paulo state, Brazil. The identification of the sandfly fauna and investigation of some ecological aspects of its populations in areas frequented by tourists of the PEI, an Atlantic forest reserve with many caves, were the objective of this study. Captures were undertaken monthly from January 2001 to December 2002, with automatic light traps installed in 13 ecotopes, including caves, forests, domiciliary and peridomiciliary environments, and by aspiration in armadillo burrows. Additionally, although not at regular intervals, Shannon traps were installed in forests and anthropic environments, aspirations were made on cave walls, among roots and fallen leaves, and some insects were captured while biting researchers. A total of 891 sandflies belonging to 21 species were captured. Six hundred specimens representing 19 species were captured with light traps, 215 in anthropic (2.24 insects/trap) and 385 in extra-domiciliary (1.46 insects/trap) environments. Brumptomyia troglodytes was the most abundant species (the Standardised Index of Species Abundance $=0.705$ ). Pintomyia monticola predominated in the Shannon traps and showed anthropophilic and diurnal activity. Psathyromyia pascalei predominated in the aspirations; the largest number being in armadillo burrows. Eleven species were captured in caves; although some might be troglophiles, the majority used these ecotopes as resting places. Nyssomyia intermedia, Nyssomyia neivai and Migonemyia migonei, implicated in the transmission of cutaneous leishmaniasis in the Southeastern Brazilian region, were all found, though in such low densities as to suggest minimal risk of the disease in the PEI.
\end{abstract}

KEYWORDS. Atlantic forest; cave; leishmaniasis; vectors.

RESUMO. Phlebotominae (Diptera, Psychodidae) na Província Espeleológica do Vale do Ribeira - 1. Parque Estadual Intervales (PEI), estado de São Paulo, Brasil. A identificação da fauna flebotomínea e de alguns aspectos ecológicos de suas populações em áreas freqüentadas por turistas no PEI, situado em reserva de mata Atlântica, constituem-se nos objetivos deste estudo. As capturas foram mensais de janeiro/2001 a dezembro/2002, com armadilhas automáticas luminosas em 13 ecótopos, incluindo cavernas, matas e peridomicílio e aspiração em tocas de tatus. Sem intervalos regulares, foram realizadas capturas com armadilhas de Shannon na mata e ambientes antrópicos, aspiração em paredes de cavernas e entre raízes e folhedo e em membros da equipe quando picados por flebotomíneos. No total foram capturados 891 flebotomíneos pertencentes a 21 espécies. Com as armadilhas automáticas luminosas capturou-se 19 espécies e 600 espécimes, 215 em ambiente antrópico (2,24 insetos/armadilha) e 385 em ambiente natural (1,46 insetos/armadilha). Brumptomyia troglodytes foi a mais abundante, com o índice de abundância das espécies padronizado $=0,705$. Pintomyia monticola predominou nas armadilhas de Shannon, mostrando-se antropofílica e com atividade hematofágica diurna e noturna. Psathyromyia pascalei predominou nas aspirações, com a maioria dos espécimes aspirados de tocas de tatu. Das 11 espécies capturadas em cavernas, embora algumas possam ser consideradas troglófilas, a maioria usa este ecótopo como local de abrigo. Nyssomyia intermedia, Nyssomyia neivai e Migonemyia migonei, implicados na transmissão da leishmaniose tegumentar na Região Sudeste do Brasil foram capturados, todavia em tão baixa densidade que sugere risco mínimo da doença no PEI.

PALAVRAS-CHAVES. Floresta Atlântica; caverna; leishmaniose; vetores.

One of the greatest concentrations of karst areas in the world, many of which offer conditions which favor the formation of caves, is found in Brazil (Auler 2002). The rock formations of the Açungui group, is the Speleological Province of the Ribeira Valley situated in southeastern Brazil, between the south of São Paulo and the north of Paraná states (Karmann \& Ferrari 2002), being the best known Brazilian karst province from the biospeleological point of view (Trajano 1984). A great part of this province is situated on the Serra de Paranapiacaba, on the west bank of the Ribeira de
Iguape River, mainly in two forest reserves: Parque Estadual do Alto Ribeira (PETAR), with more than 300 caves and the Parque Estadual Intervales (PEI) with about 50 caves (São Paulo 2008). This great concentration of caves and the extensive continuous remnant of Atlantic forest make this an important tourist attraction.

Among the inhabitants of caves and forests are the phlebotomines (Diptera, Psychodidae) (Aguiar \& Medeiros 2003; Andrade Filho et al. 2001; Galati et al. 2003, 2006), the females of which are hematophagous, biting mammals, birds 
and cold-blooded animals. Many species are anthropophilic and beyond bothering humans by their painful bites, which sometimes result in allergic manifestations, may be vectors of viruses, bacteria and Trypanosomatidae (Forattini 1973; Young \& Duncan 1994). Among these latter, several species of the genus Leishmania are of particular interest as agents of leishmaniases which constitute a serious public heath problem due to the complexity of their clinical manifestations (visceral, muco-cutaneous, diffuse and cutaneous) and epidemiology. The leishmaniases occur in 88 countries with an estimated annual incidence of 1.5 million new cases of cutaneous forms and 500,000 new cases of the visceral form, with an overall prevalence of 12 million people infected and a total population of 350 million at risk worldwide. Brazil is among the five countries which together account for $90 \%$ of the visceral cases and the seven in which $90 \%$ of all cutaneous cases have been registered (Desjeux 2004).

The Ribeira Valley region, with 1,174 cases registered between 1998 and 2006 and an average annual coefficient of 47.7 new infections/100,000 inhabitants, has one of the highest incidences of human American cutaneous leishmaniasis cases in the State of São Paulo. The respective coefficients found in the municipalities in which the PETAR and the PEI are situated were, during this same period: Guapiara (1.6 new infections/100,000), Ribeirão Grande $(2.74 / 100,000)$, Apiaí $(5.6 / 100,000)$, Sete Barras $(8.5 / 100,000)$, Eldorado $(144.8 / 100,000)$ and Iporanga $(152.9 / 100,000)$ (CVE 2007).

The phlebotomine fauna of the Ribeira Valley has been relatively well investigated and the behavior of the probable vectors of cutaneous leishmaniasis has been the most extensively studied, mainly in peridomiciliary and cultivated areas (Forattini et al. 1976; Gomes et al. 1980, 1982, 1983, 1986; Gomes \& Galati 1987, 1989; Domingos et al. 1998; Taniguchi et al. 2002). However, no information relating to the phlebotomines in the Speleological Province of the Ribeira Valley has been found in the literature by these present authors, despite its having been investigated for a great number of organisms (Pinto-da-Rocha 1994; Trajano 2000). Certain human activities such as ecological tourism, research, mining, surveillance by forest wardens, colonization and others, undertaken in this province in forested and/or speleological areas, increase the chances of people's coming into contact with phlebotomine populations. So the objective adopted for this present project, in 2001 and 2002, was to identify the phlebotomine fauna and some aspects of its behavior in some of the caves situated in the PEI as well as in the forest and anthropic environments in the province, to investigate the exposure of the human population to the sandfly species in the area.

\section{MATERIAL AND METHODS}

Study area. The Parque Estadual Intervales (Fig. 1), situated between the Ribeira Valley and the southwest of São Paulo state $\left(24^{\circ} 12^{\prime}-24^{\circ} 25^{\prime} \mathrm{S}\right.$ and $48^{\circ} 03^{\prime}-48^{\circ} 30^{\prime}$ W), occupies an area, at the present time, of 41,704 hectares, forming part of the Paranapiacaba massif. Together with three other reserves: the Estação Ecológica Xitué to the north, the
Parque Estadual Carlos Botelho to the east, and the Parque Estadual do Alto Ribeira (PETAR) to the southwest, it forms a continuous protected forest with a total area of approximately 120,000 ha. Its altitude varies from $60 \mathrm{~m}$ in the extreme east to $1,095 \mathrm{~m}$ on the northwestern limit (Carvalho et al. 2002).

The predominant climate is temperate without any dry season: $\mathrm{Cfb}$ according to Koeppen's International System (Köppen 1948). The annual average temperature varies from $17^{\circ} \mathrm{C}-19^{\circ} \mathrm{C}$, but the minimum may come close to zero in the coldest period (Gnaspini-Netto \& Trajano 1992). The annual average rainfall is of approximately $1,600 \mathrm{~mm}$ in the upland areas $(800 \mathrm{~m})$ (SIGRH 2007), but in the lower areas may attain 4,000 $\mathrm{mm}$ (Morellato et al. 2000).

Atlantic rain forest, a transitional domain between dense ombrophilous mountain forest and mixed ombrophilous forest, constitutes the predominant vegetation. The dense ombrophilous submountain forest is present also in the lower areas.

The calcareous stratum, in which the approximately eighty known caves of the Parque Estadual Intervales are located, extends in a north-westerly direction to the PETAR. The area covered by these calcareous rocks may be divided, according to Gnaspini-Netto \& Trajano (1992), into the following regions: Sede, Pedra do Fogo, Bocaina, Capoava, Figueira and Bulha d'Água (Fig. 1). In the present study three regions: Bocaina and Pedra do Fogo, about four $\mathrm{km}$ from each other, and Sede, very close to the latter, were sampled.

In the Bocaina region two caves: Minotauro and Barra Bonita, as well as the vegetation surrounding this latter, were sampled regularly. The Minotauro cave ( $24^{\circ} 16^{\prime} 2200^{\prime \prime} \mathrm{S}, 48^{\circ}$ $27^{\prime} 2200$ ” W, $890 \mathrm{~m}$ above sea level) presents a horizontal projection of $400 \mathrm{~m}$, a discontinuous linear development of $560 \mathrm{~m}$, a $25 \mathrm{~m}$ drop in level and a large entrance, and is accessible to tourists. The Barra Bonita cave $\left(24^{\circ} 16^{\prime}\right.$ $0300^{\prime \prime} \mathrm{S}, 48^{\circ} 27^{\prime} 2400^{\prime \prime} \mathrm{W}, 855 \mathrm{~m}$ a.s.1.), with a horizontal projection of $135 \mathrm{~m}$, linear development of $162 \mathrm{~m}$ and a 14 $\mathrm{m}$ drop in level, is closed to tourists. The local vegetation is well preserved secondary forest with many epiphytes and also some bamboos (Merostachys sp.) (Carvalho et al. 2002). Close to the trail which crosses the Bocaina river there is an area of deteriorated pasture, approximately $200 \mathrm{~m}$ from the caves. These caves are accessible on foot from this pasture.

In this region, three other caves were visited sporadically: Paivas: (24 $16^{\prime} 11^{\prime \prime} \mathrm{S}, 48^{\circ} 26^{\prime} 32^{\prime \prime} \mathrm{W}$; $780 \mathrm{~m}$ a.s.l.) the largest in the region, with a delineated linear development of 2,880 $\mathrm{m}$, presents one main entrance and two others of more difficult access and a skylight situated in one of the upper level halls. Fendão cave ( $24^{\circ} 16^{\prime} 11^{\prime \prime} \mathrm{S}, 48^{\circ}, 26^{\prime} 55^{\prime \prime}$ W, 825 $\mathrm{m}$ a.s.1.), with a development of $1,120 \mathrm{~m}$, of which $400 \mathrm{~m}$ are galleries of the Bocaina river, has several accesses to the

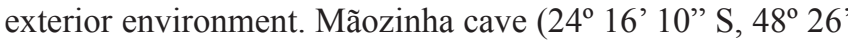
$55^{\prime \prime} \mathrm{W} ; 835 \mathrm{~m}$ a.s.1.) consists of a gallery of $62 \mathrm{~m}$, with a small upper opening.

In the Pedra do Fogo region, only the Colorida cave and surrounding vegetation were sampled regularly. The Colorida cave (24 $16^{\prime} 1300^{\prime \prime} \mathrm{S}, 48^{\circ} 25^{\prime}$ '0900" W, $825 \mathrm{~m}$ a.s.l.) presents a horizontal projection of $765 \mathrm{~m}$, linear development of 987 


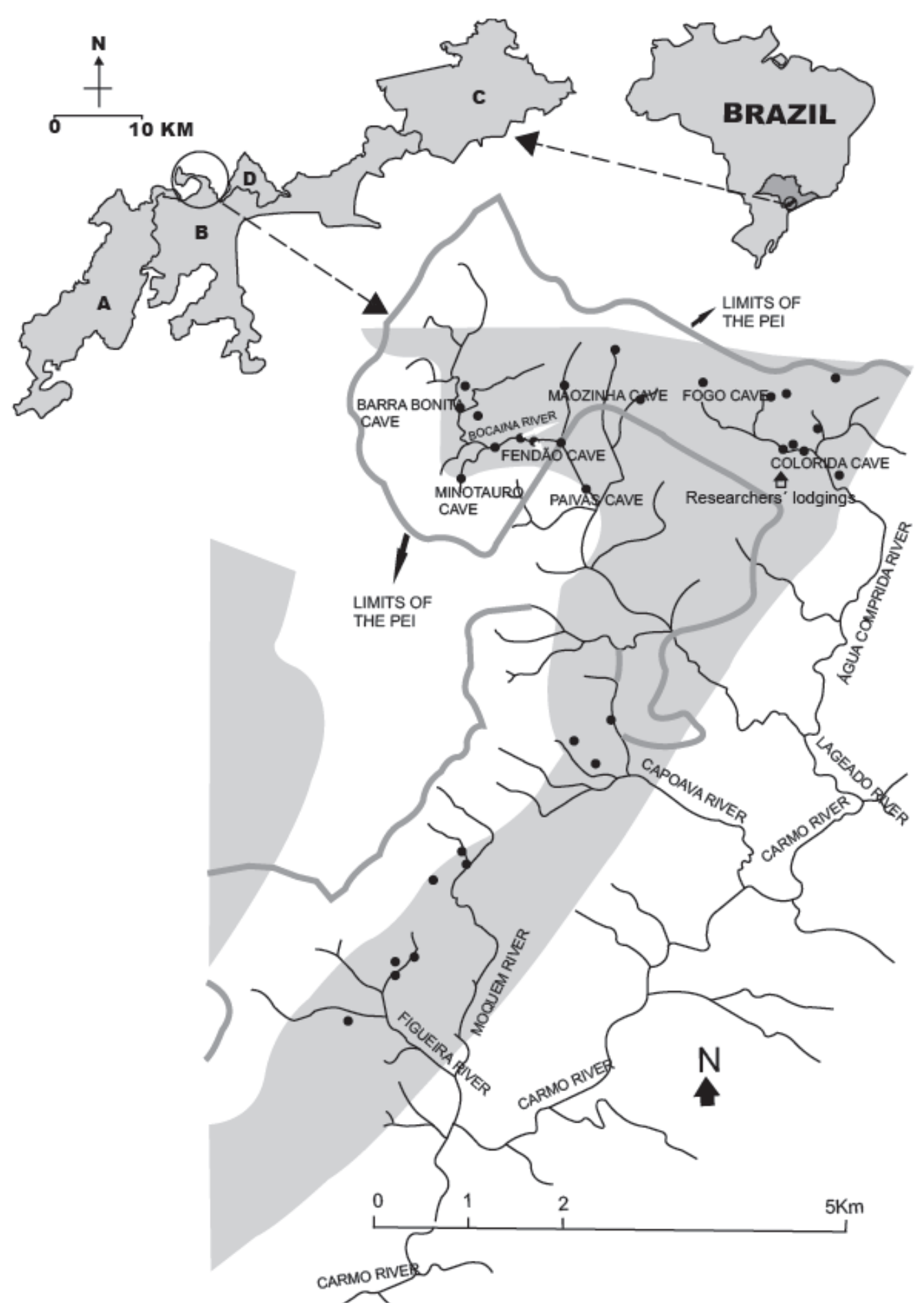

Fig. 1. Area of the Ecological Continuum (A-D). A, Parque Estadual Turístico do Alto Ribeira (PETAR). B, Parque Estadual Intervales (PEI). C, Parque Estadual Carlos Botelho and D, Estação Ecológica Xitué, and localization of some caves and the anthropic environment (researchers' lodging) studied in the PEI; grey area represents the calcareous stratum. Source: adapted from Gnaspini-Netto \& Trajano (1992).

$\mathrm{m}$ and a drop in level of $25 \mathrm{~m}$. Its principal entrance is small. It is often visited by tourists. The vegetation of this region consists of young secondary forest areas in which bamboos and lianas are abundant, there being many pioneer species and very dense undergrowth. The maximum height of the forest is $25 \mathrm{~m}$. (Carvalho et al. 2002). Some trails traverse this vegetation. The Fogo cave $\left(24^{\circ} 15^{\prime} 4900^{\prime \prime} \mathrm{S}, 48^{\circ} 25^{\prime}\right.$,
4800 " W, $950 \mathrm{~m}$ a.s.1.), having a horizontal projection of 126 $\mathrm{m}$, linear development of $163 \mathrm{~m}$ and a drop in level of $15 \mathrm{~m}$, with a large entrance, and the Cipó cave (24 16' 12.82193" S, $48^{\circ} 24^{\prime} 59.76557^{\prime}$ W, $783 \mathrm{~m}$ a.s.1.) with $60 \mathrm{~m}$ of linear development and a small entrance were visited sporadically.

The Sede (headquarters) is situated in the NW region of the park at $860 \mathrm{~m}$ a.s.l. It is in this area that the reception 
office, tourist lodgings, restaurant, center for recreational activities and conferences, areas for visitors, with bathrooms and kiosks and also the research headquarters, are installed. The area in which the headquarters is located is relatively flat, but is surrounded by hills, the height of which varies between 100 and $200 \mathrm{~m}$ above this plain. Apart from several streams crossing the area, there are also artificial lagoons and small reservoirs. Among the vegetation around the Sede, young secondary forest in which bamboo, "embaúba" (Cecropia spp) and "manacá-da serra" (Tibouchina spp) are abundant is predominant. Preserved old secondary forest may be found in some areas, mainly at the bottom of some valleys (Carvalho et al. 2002).

Methodology. Three techniques were employed for the captures, undertaken from January 2001 to December 2002: automatic light traps (Natal et al. 1991), modified by having a no-break battery (6 volts and 12 amperes) as energy source and an external collection chamber linked to the body of the trap by a sleeve, modified black or white Shannon traps (Galati et al. 2001), and aspiration.

The automatic light traps were installed monthly, in a total of 13 ecotopes, with the following distribution:

Bocaina region (six ecotopes): i) in the Minotauro cavemouth, in a twilight area; ii) in Barra Bonita cave-mouth and iii) its interior; iv) in forest canopy (at $\sim 15 \mathrm{~m}$ height); $v$ ) in forest, above ground $(1.0 \mathrm{~m}$ ) and $v i$ ) at edge of forest (at $\sim 2 \mathrm{~m}$ height), around the Barra Bonita cave.

Pedra do Fogo region (five ecotopes): i) in Colorida cave (in a dark zone); ii) in a cavity of the external wall of the Colorida cave, approximately $5.0 \mathrm{~m}$ from its main entrance; iii) in forest canopy (at $\sim 15.0 \mathrm{~m}$ height); iv) in forest, above ground $(1.0 \mathrm{~m})$ and $v$ ) at the edge of the forest (at $2.0 \mathrm{~m}$ height), around the Colorida cave.

Sede (two ecotopes related to the researchers' lodgings, with constant presence of hosts): i) on the veranda (at $3.0 \mathrm{~m}$ height) and ii) in the peridomicile (the trap was installed at $2.0 \mathrm{~m}$ height in a bush situated $c a .100 \mathrm{~m}$ from the house).

Several sites were sampled with modified white and/or black Shannon traps, at irregular time intervals. Members of the team made the captures monthly with the help of a guide, in two distinct areas, between 6.00 p.m. and 10.00 p.m. Two members of the team captured the insects in each area for the investigation of natural infection by flagellates as described by Galati et al. (2003). Occasionally, the guide, during his activities in the PEI, undertook captures with a black trap. The sites sampled were: forest, surrounding the Colorida, Minotauro, Barra Bonita, Cipó, Fogo and Paivas caves, and in the Sede region: São Inácio's church, another small church, the craftsman's house, the stone house, Tower trail, Morro do Espia trail, on the edge of the old lagoon, at the lake-side, in the peridomiciles of the researchers' lodgings and on Paiva's small-holding, about $3 \mathrm{~km}$ from the Sede, outside the park (Fig. 2).

Aspiration was carried out monthly with an electrical aspirator (6 volts) for one hour between 9.00 and 11.00 a.m. to investigate the presence of phlebotomines in armadillo burrows in a forested area round the researchers' lodgings.

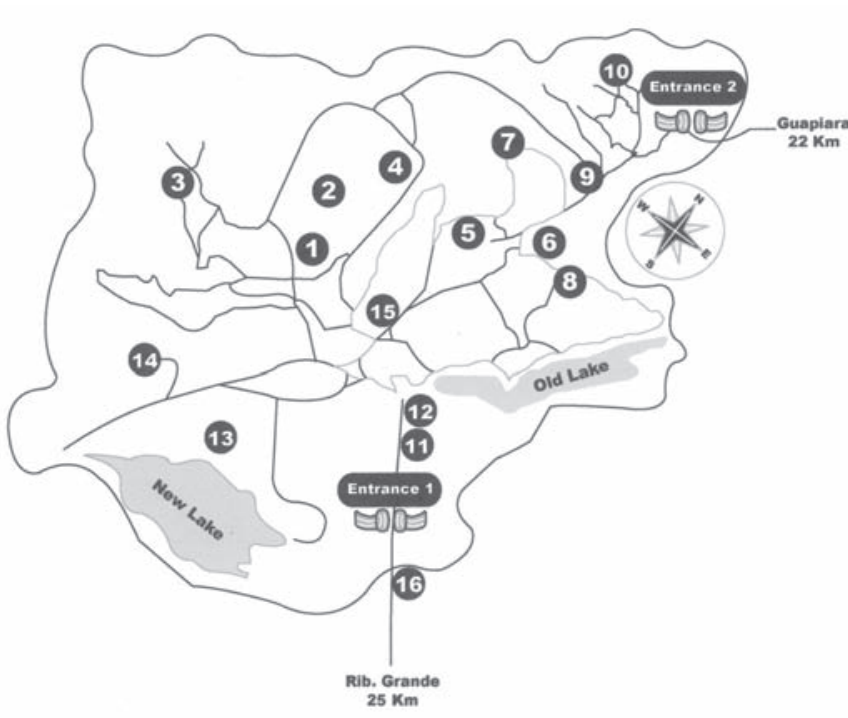

Fig. 2. Scheme of the principal administrative and tourist center (Sede) of the Parque Estadual Intervales and some touristic points and caves investigated. 1, researchers' lodging. 2, Colorida cave. 3, Água Comprida waterfall. 4, Cipó cave. 5, Artesão's house. 6, Santo Inácio church. 7, Morro do Espia tower. 8, Minotauro cave. 9, Fogo cave, 10, stone house. 11, tourist lodging. 12 , administrative office, 13 , reception office. 14 and 15 , tourist lodgings. 16, small church and Paiva's small farm.

Some sporadic aspirations were made on the internal and/or external walls of caves and on the trunks and roots of trees, among fallen leaves and in holes in rocks.

Apart from the females dissected, the specimens captured with automatic light traps and those captured with the other techniques, after being killed in chloroform were conditioned in Petri dishes and kept under refrigeration until their clarification by the method described by Forattini (1973) and identification in accordance with Galati (2003). The abbreviation of the generic name of the species follows Marcondes (2007). A sample of these specimens is deposited in the collection of the Departamento de Epidemiologia of the Faculdade de Saúde Pública, USP.

The pluviometric data of the PEI were obtained from the Intervales meteorological station (810 m a.s.l.) (SIGRH 2007) and the temperature data of Capão Bonito municipality (900 $\mathrm{m}$ a.s.1.), which borders the PEI, from the Centro Integrado de Informações Agrometeorológicas do Instituto Agronômico de Campinas (CIIAGRO 2007).

Statistical analysis. The frequency of insects captured in armadillo burrows by seasonal variation was obtained by Williams' geometric average (Haddow 1960).

For the abundance and diversity calculations, the data used were those of the captures carried out with automatic light traps. The Standardised Index of Species Abundance (SISA) was calculated in accordance with Roberts \& Hsi (1979) and Shannon's Diversity Index $(\mathrm{H})$ and Pielou's Evenness Index (J) in accordance with Hayek and Buzas (1997).

The $\chi^{2}$ test was used for the comparison between the numbers of insects captured during the same period at two different sites, as also between the numbers of insects captured in armadillo burrows in different seasons. 
Table I. Numbers of specimens, by species and sex, captured with automatic light traps at the thirteen ecotopes sampled with respective Shannon diversity (H) and Pielou evenness $(J)$ indexes in the regions of Pedra do Fogo, Sede and Bocaina in PEI, from January 2001 to December 2002.

\begin{tabular}{|c|c|c|c|c|c|c|c|c|c|c|c|c|c|c|c|c|c|c|c|c|c|c|c|c|c|c|}
\hline \multirow{3}{*}{ Species } & \multicolumn{8}{|c|}{ Pedra do Fogo } & \multicolumn{4}{|c|}{ Sede } & \multicolumn{12}{|c|}{ Bocaina } & \multirow{2}{*}{\multicolumn{2}{|c|}{ Total }} \\
\hline & \multicolumn{3}{|c|}{$\begin{array}{cc}\text { Colo- } & \text { Colo- } \\
\text { rida } & \text { rida } \\
\text { cave } & \text { external } \\
\text { interior wall }\end{array}$} & $\begin{array}{l}\text { forest } \\
\text { cano- } \\
\text { py }\end{array}$ & \multicolumn{4}{|c|}{$\begin{array}{l}\text { forest forest } \\
\text { ground edge }\end{array}$} & \multicolumn{2}{|c|}{$\begin{array}{l}\text { Domi- } \\
\text { cile }\end{array}$} & \multicolumn{2}{|c|}{$\begin{array}{l}\text { Perido- } \\
\text { micile }\end{array}$} & \multicolumn{2}{|c|}{$\begin{array}{l}\text { Mino- } \\
\text { tauro } \\
\text { cave } \\
\text { interior }\end{array}$} & \multicolumn{2}{|c|}{$\begin{array}{l}\text { Barra } \\
\text { Bonita } \\
\text { cave } \\
\text { interior }\end{array}$} & \multicolumn{2}{|c|}{$\begin{array}{c}\text { Barra } \\
\text { Bonita } \\
\text { external } \\
\text { wall }\end{array}$} & \multicolumn{2}{|c|}{$\begin{array}{c}\text { forest } \\
\text { cano- } \\
\text { py }\end{array}$} & \multicolumn{2}{|c|}{$\begin{array}{l}\text { forest } \\
\text { ground }\end{array}$} & \multicolumn{2}{|c|}{$\begin{array}{l}\text { forest } \\
\text { edge }\end{array}$} & & \\
\hline & $\mathrm{M} \mathrm{F}$ & $\mathrm{F} \quad \mathrm{M}$ & $\mathrm{F} I$ & M F & $\mathrm{F} \quad \mathrm{M}$ & $\mathrm{F}$ & M & $\mathrm{F}$ & $\mathrm{M} \mathrm{I}$ & $\mathrm{F} \quad \mathrm{I}$ & M I & $\mathrm{F}$ & M & $\mathrm{F}$ & M & $\mathrm{F}$ & M & $\mathrm{F}$ & M & $\mathrm{F}$ & $\mathrm{M}$ & $\mathrm{F}$ & & $\mathrm{F}$ & MF & $\%$ \\
\hline Br. bragai Sherlock & - & - & - & $-\quad-$ & - & - & - & & - & - & 2 & - & - & - & - & - & - & - & - & - & - & - & - & - & 2 & $\overline{0.4}$ \\
\hline $\begin{array}{l}\text { Br. carvalheiroi Shimabu- } \\
\text { kuro, Marassá \& Galati }\end{array}$ & 1 & -7 & 9 & $-\quad-$ & 2 & 3 & 3 & 1 & 42 & 4 & $1 \varepsilon$ & 8 & - & 1 & - & _ & - & - & - & - & 2 & 1 & & - & 47 & 7.8 \\
\hline Br. cunhai (Mangabeira) & - & -4 & 1 & $-\quad-$ & 1 & - & - & 1 & -1 & 1 & 1 & - & 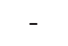 & & - & 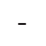 & - & - & 1 & 1 & - & - & 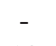 & - & 11 & 1.8 \\
\hline lodytes (Lutz) & - & -3 & 7 & 31 & 11 & 2 & - & 3 & 865 & 22 & 281 & 17 & - & - & - & - & 9 & 3 & 50 & 20 & 16 & 2 & 10 & 8 & 321 & 53.4 \\
\hline $\begin{array}{l}\text { v. correalimai (Martins, } \\
\text { outinho \& Luz) }\end{array}$ & - & -1 & 2 & $-\quad-$ & - & - & - & - & - & - & - & - & - & - & - & - & - & - & - & - & - & - & - & - & 3 & 0.5 \\
\hline (Mangabeira) & - & 12 & 36 & -1 & 1 & - & - & 6 & - & 1 & - & - & - & - & - & - & - & - & - & - & - & - & . & - & 49 & 8.2 \\
\hline $\begin{array}{l}\text { x. firmatoi (Barretto, Mar- } \\
\text { ns \& Pellegrino) }\end{array}$ & - & 31 & 1 & $-\quad-$ & - & - & - & - & - & - & - & - & . & - & - & & - & - & - & - & - & - & - & - & 5 & 0.8 \\
\hline $\begin{array}{l}\text { Mg. rabelloi (Galati \& } \\
\text { Gomes) }\end{array}$ & - & - & - & $-\quad-$ & - & - & - & - & - & - & - & - & - & - & - & - & - & - & - & 1 & - & - & - & - & 1 & 0.2 \\
\hline $\begin{array}{l}\text { Mi. petari Galati, Marass } \\
\text { Gonçalves-Andrade }\end{array}$ & - & - & 4 & $-\quad-$ & - & - & - & - & - & - & - & - & 1 & 3 & - & - & - & - & - & - & - & - & 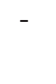 & - & 11 & 1.8 \\
\hline$a$ (Lutz \& & - & 1 & - & - & - & - & - & - & - & - & - & - & - & - & 1 & 1 & - & - & - & - & - & - & - & - & 3 & 0.5 \\
\hline ) & - & $-\quad-$ & - & $-\quad-$ & - & 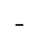 & - & - & - & - & - & - & 1 & - & - & 6 & - & - & - & - & - & 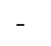 & . & 1 & 8 & 1.3 \\
\hline$y$. & 1 & $-\quad-$ & - & $-\quad-$ & - & - & - & - & - & - & - & 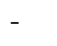 & - & - & - & - & - & - & - & - & - & - & - & - & 1 & 0.2 \\
\hline (Barretto \& & 3 & $\begin{array}{ll}2 & 14\end{array}$ & 13 & 13 & 2 & 12 & 8 & 12 & -3 & 3 & 1 & - & - & - & - & - & - & - & - & 1 & - & & 3 & 3 & 81 & 13.5 \\
\hline $\begin{array}{l}\text { Pa. pascalei (Coutinho \& } \\
\text { Barretto) }\end{array}$ & - & -3 & 1 & - & 6 & 5 & 2 & - & -1 & 1 & 1 & 1 & 2 & 1 & - & - & - & 1 & - & - & - & - & - & - & 24 & 4.0 \\
\hline Pa. s & - & 1 & - & $-\quad-$ & - & - & - & 1 & - & - & 1 & & 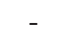 & 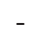 & - & 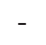 & - & - & - & - & - & - & - & 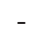 & 5 & 8 \\
\hline Pi.f & - & - & - & -1 & - & - & - & - & - & - & - & . & - & - & - & - & - & - & - & - & - & - & - & - & 1 & 0.2 \\
\hline Pi. n & - & $2-$ & 5 & $-\quad-$ & - & - & - & - & - & - & - & - & - & 5 & - & - & - & 1 & - & 2 & - & 2 & - & 6 & 23 & 3.8 \\
\hline Ps. ayrozai (Barretto \& & - & - & - & $-\quad-$ & - & - & - & 1 & - & - & - & - & - & - & - & - & - & - & - & - & - & - & - & - & 1 & 0.2 \\
\hline $\begin{array}{l}\text { Ps. geniculatus (Manga- } \\
\text { beira) }\end{array}$ & - & - & - & - & - & 1 & - & - & -1 & 1 & - & - & - & - & - & - & - & - & - & - & - & - & - & - & 2 & 0.4 \\
\hline Sc. microps (Mangabeira) & - & - & & $-\quad-$ & - & - & - & - & - & - & - & 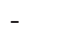 & - & - & 1 & - & - & - & - & - & - & - & - & & 1 & 0.2 \\
\hline & $\begin{array}{ll}5 & 12\end{array}$ & 1236 & & 46 & & & 13 & & 906 & & & & & & 1 & 0 & 9 & 5 & & 25 & 18 & 5 & & 18 & & 1000 \\
\hline Tot & 1 & & 15 & 10 & & & & & 153 & & 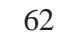 & & & & & & 1 & & 76 & 6 & 23 & & 31 & 1 & & 00 \\
\hline $\mathrm{H}$ & 1.422 & 21.5 & 905 & 1.19 & & & 1.50 & 07 & 0.46 & & 0.97 & & & & & & 0.5 & 11 & .38 & 384 & 0.6 & & 1.0 & 62 & & 904 \\
\hline - & 0.684 & & 794 & 0.861 & 10.7 & 81 & 0.72 & 25 & 0.23 & & 0.50 & & 0.87 & & 0.7 & & 0.4 & 65 & 0.23 & 39 & 0.6 & & 0.7 & 766 & & 636 \\
\hline
\end{tabular}

* specimen without genitalia. Br. = Brumptomyia; Ev. = Evandromyia; Mg. = Migonemyia; Mi. = Micropygomyia; Ny. = Nyssomyia; Pa. $=$ Psathyromyia; Pi. = Pintomyia; Ps. = Psychodopygus; Sc. = Sciopemyia.

\section{RESULTS}

A total of 891 sandfly specimens belonging to 21 species were captured in the PEI, with the three techniques described. Nineteen species were obtained with the automatic light traps (Table I), 14 on the Shannon traps (Table II) and 7 by aspiration (Table III). Only two of the species were not captured with the automatic light traps: $M g$. migonei (França) was only captured with the Shannon trap and Sc. sordellii (Shannon \& Del Ponte) by aspiration.

The numbers of specimens, by species and sex, captured in the Pedra do Fogo, Sede and Bocaina regions with automatic light traps in the thirteen ecotopes with the respective Shannon diversity $(\mathrm{H})$ and Pielou evenness $(\mathrm{J})$ indices, calculated for both sexes together, are presented in Table I. Of the 600 sandflies captured with automatic light traps, 215 (average of 4.48 insects/trap) were collected in anthropic environments (domiciliary and peridomiciliary) and 385 (1.46 insects/trap) in the extra-domiciliary environments (caves and forests). In the five ecotopes of the Pedra do Fogo region, including one cave, 218 sandflies (1.82 insects/trap) were captured, and in the six ecotopes of the Bocaina region, with two caves, 167 (1.16 insects/trap). In the extra-domiciliary environment of the Pedra do Fogo region, Pa. lanei predominated (32.0\%), followed by Ev. edwardsi (22.0\%). This latter species predominated in the cavity of the external rocky walls of the Colorida cave $(33.0 \%)$ and $\mathrm{Pa}$. lanei in all of the other ecotopes: Colorida cave $(29.4 \%)$, canopy $(40.0 \%)$, ground 
$(36.8 \%)$ and forest edge (52.6\%). In the Bocaina region, in the Minotauro cave Pi. monticola predominated (35.7\%), and in the Barra Bonita cave Ny. neivai (66.7\%). In all the other ecotopes, Br. troglodytes was captured with the highest frequencies: at the entrance of the Barra Bonita cave (85.7\%), in the canopy $(92.1 \%)$, on the ground $(78.3 \%)$ and at the forest edge $(58.1 \%)$. In the domiciliary and peridomiciliary environments, Br. troglodytes represented $90.2 \%$ and $72.6 \%$, respectively, of the total captured.

The highest species richness and Shannon diversity index were found in the Pedra do Fogo region. In the cavity of the external wall of the Colorida cave (11 species and $\mathrm{H}=1.905$ ). In all the ecotopes of this region, excepting the canopy with the presence of four species, the others had similar species richness (8), but on the forest ground the Shannon diversity index was the greater $(\mathrm{H}=1.625)$ than in the others. In the Bocaina region, both the Minotauro cave and forest canopy had similar species richness (5), but the Shannon diversity index was highest in the Minotauro cave $(\mathrm{H}=1.402)$ and lowest in the canopy (0.384).

The highest evenness Pielou indices were observed in the Minotauro cave $(\mathrm{J}=0.871)$, in the Bocaina region, and canopy $(\mathrm{J}=0.861)$ in the Pedra do Fogo region, whereas the lowest and equal indices $(\mathrm{J}=0.239)$ were observed in the domicile of the Sede and canopy of the Bocaina region, both greatly influenced by the large numbers of Br. troglodytes (Table I).

The seasonal frequencies (insects/season) of both sexes of Br. troglodytes, calculated by the Williams' average, in the two ecotopes where the species was more numerous during the period January 2001 to December 2002 (Domicile - Sede region and canopy - Bocaina region), were, respectively: summer $(2.83 ; 2.26)$, autumn $(0.0 ; 0.0)$, winter $(0.0 ; 0.0)$ and spring $(3.93 ; 0.35)$. Thus this species was clearly associated with more humid and hotter periods, as may be observed in Figure 3.

The numbers of captures undertaken with black (B) and/ or white (W) Shannon traps by site and those of insects captured, and the numbers of hours dedicated to the captures, were: in the Bocaina Region: in front of the cave entrances: Minotauro (1B, 2 h. - Pi. monticola 3 q and 1W, 2 h. - Mi. petari 10ิ, Pi. monticola 10ิ, 2ᄋ); Barra Bonita 1B, 3 h. Ps. geniculatus 1ठ, Br. troglodytes 1 ; ; Paivas 1B, 4 h. negative; inside forest 3B, $12 \mathrm{~h}$. $1 \mathrm{~W} 4 \mathrm{~h}$ - negative. Pedra do Fogo Region: in front of the cave entrances: Colorida (17 B, 64 h. - Ev. edwardsi $1 \partial^{\lambda} 7$; ; Ex. firmatoi $2 \widehat{\bigcirc} 1$ P Pi. monticola

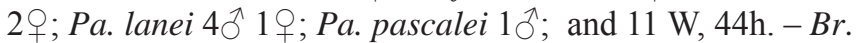

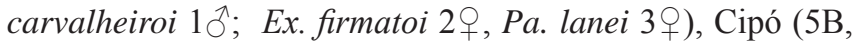
18 h. - Ev. edwardsi 3 , Pa. lanei $3+$, Ps. ayrozai $2+$, Ps. geniculatus 19 and $2 \mathrm{~W}, 8 \mathrm{~h}$. - Ev. edwardsi 19 , Pa. lanei 2 + $)$ and Fogo (3 B, 13 h. - Ev. edwardsi 3 , , Pi. monticola 2o, Ps. ayrozai 19,); Sede Region: on the forest tracks: Tower (1B, $2 \mathrm{~h}$ - negative, $1 \mathrm{~W} 2 \mathrm{~h}$. - negative), Água Comprida waterfall (2B, 7 h. - Pi. monticola $19, P a$. sp. 19 and $2 \mathrm{~W} 7$ h. $-P a$. pascalei 1 우) and Morro do Espia (1B, $4 \mathrm{~h}$. - negative), on the veranda of the domiciles Artesão's house (3B, 12h. and $4 \mathrm{~W} 16 \mathrm{~h}$. - negative) and researchers' house (1B, $4 \mathrm{~h} .1 \mathrm{~W}$, $4 \mathrm{~h}$. - negative), beside the churches: Igrejinha (7B, $18 \mathrm{~h}-$

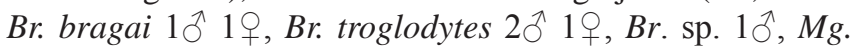

Table II. Number of phlebotomines, by sex, captured with black or white Shannon traps in forests of the PEI, from January 2001 to December 2002.

\begin{tabular}{|c|c|c|c|c|c|c|c|c|}
\hline \multirow{3}{*}{$\begin{array}{r}\text { Species } \\
\text { no. captures } \\
\left(n^{\circ} \text { hours }\right) \\
\text { sex }\end{array}$} & \multirow{2}{*}{\multicolumn{2}{|c|}{$\begin{array}{c}\text { Black } \\
50 \text { (158 h.) }\end{array}$}} & \multirow{2}{*}{\multicolumn{2}{|c|}{$\begin{array}{c}\text { White } \\
25 \text { (95 h.) }\end{array}$}} & \multirow{2}{*}{\multicolumn{4}{|c|}{$\begin{array}{c}\text { Total } \\
75 \text { (253 h.) }\end{array}$}} \\
\hline & & & & & & & & \\
\hline & M & $\mathrm{F}$ & M & $\mathrm{F}$ & M & $\mathrm{F}$ & MF & $\%$ \\
\hline Br. bragai & 1 & 1 & - & - & 1 & 1 & 2 & 1.37 \\
\hline Br. carvalheiroi & 1 & 1 & 1 & - & 2 & 1 & 3 & 2.06 \\
\hline Br. troglodytes & 2 & 2 & - & - & 2 & 2 & 4 & 2.74 \\
\hline Ev. edwardsi & 1 & 13 & - & 1 & 1 & 14 & 15 & 10.27 \\
\hline Ex. firmatoi & 2 & 1 & - & 2 & 2 & 3 & 5 & 3.42 \\
\hline Mg. migonei & 1 & 1 & - & - & 1 & 1 & 2 & 1.37 \\
\hline Mi. petari & - & - & 1 & - & 1 & - & 1 & 0.69 \\
\hline Ny. neivai & - & 1 & - & - & - & 1 & 1 & 0.69 \\
\hline Pa. lanei & 4 & 6 & - & 4 & 4 & 10 & 14 & 9.59 \\
\hline Pa. pascalei & 1 & 1 & - & - & 1 & 1 & 2 & 1.37 \\
\hline Pa.sp. & - & 2 & - & - & - & 2 & 2 & 1.37 \\
\hline Pi. monticola & - & 87 & 1 & 2 & 1 & 89 & 90 & 61.64 \\
\hline Ps. ayrozai & - & 3 & - & - & - & 3 & 3 & 2.05 \\
\hline Ps. geniculatus & 1 & 1 & - & - & 1 & 1 & 2 & 1.37 \\
\hline Total & 14 & 120 & 3 & 9 & 17 & 129 & 146 & 100.0 \\
\hline
\end{tabular}

Br. = Brumptomyia $;$ Ev. = Evandromyia $;$ Ex. = Expapillata; $M g .=$ Migonemyia; Mi. = Micropygomyia; Ny. = Nyssomyia; Pa. = Psathyromyia; Pi. $=$ Pintomyia; Ps. $=$ Psychodopygus.

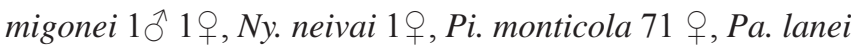
1 ,,$P a$. sp. 1우) and Santo Inácio (1B, 4 h. - negative), beside the Stone House (1W 4 h., negative), lake edge (1B, 1:30 h. - Br. sp. 19, Pi. monticola 2 \%), edge of old lagoon (1B, 1:30 h. - Pi. monticola 6 9). Peridomicile of Paiva's small farm, 3 $\mathrm{km}$ outside the PEI (1B, 4 h., 1W, 4h. - negative). So modified black and/or white Shannon traps (Table II) yielded a total of 146 sandflies representing 14 species, giving an average of $1.95 \mathrm{insects} /$ trap, $0.58 \mathrm{insects} /$ hour (black 2.68 insects/trap or 0.85 insects/hour; white 0.48 insects/trap or 0.12 insects/ hour). Pi. monticola clearly predominated on the black trap 87/134 (72.5\%). However, of this total, 61/87 (70.1\%) were captured in one single capture in the forest beside the small church (Igrejinha), in April 2002 (18.30 h.-19.30 h.). Ev. edwardsi with 14 specimens (10.4\%) was the second most attracted by the black trap. The richness on the black trap was 13 species and on the white, 6 . The females were more attracted to both traps than the males, the female/male ratio being 8.57:1:0, while on the white it was 3.0:1.0.

There was one of the captures with the black and white Shannon traps, in October 2002, on the track to the Água Comprida waterfall, in which no specimen was captured landing on the traps, but during which 17 females of Pi. monticola and two of $\mathrm{Pa}$. sp. were captured biting the researchers. Another 14 females of Pi. monticola (11.00 $15.30 \mathrm{~h})$, two of $P a$. sp. $(20.00-22.00$ h.) and one of $P a$. lanei $(21.00-22.00 \mathrm{~h})$, were captured biting one of the guides during his activities in the park, thus confirming the anthropophily of these three species and the diurnal activity of Pi. monticola.

A total of 56 females captured with automatic light and Shannon traps or biting the researchers were dissected for investigation of their digestive tracts for natural infection by flagellates with negative results, but one of Pi. monticola 
was found to be infested with microfilariae. The species and respective numbers of specimens dissected were: Brumptomyia sp. (4), Br. troglodytes (18), Ev. edwardsi (3), Ex. firmatoi (1), Mi. petari (2), Ny. neivai (1), Pa. lanei (6), Pa. pascalei (1), Pa. sp. (2) and Pi. monticola (18).

A total of 67 hours were spent on aspiration in several ecotopes, resulting in the capture of 145 specimens representing 8 species (Table III). Of this total, 94.5\% were collected in armadillo burrows, with the predominance of $\mathrm{Pa}$. pascalei (54.8\%), Br. carvalheiroi (32.8\%), Br. troglodytes $(10.2 \%)$ and Pi. monticola $2.2 \%$, with a significant statistical difference between the two most frequent species $\left(\chi^{2}=10.65\right.$; $\mathrm{p}<0.01$; f.d. $=1)$. In the total of specimens captured, the male/female ratio was 2.6:1.0. The results were negative on the internal walls of seven caves; however, five species: $\mathrm{Br}$. cunhai, Ev. edwardsi, Pi. monticola, Pa. lanei and Sc. sordellii (the one specimen captured of this latter being the only one found in the PEI), were collected on the external walls of the Colorida and Fogo caves.

The seasonal distribution of the specimens captured

Table III. Numbers of phlebotomine specimens captured by aspiration, by site, number of hours, species and sex, in the PEI, during the period from January 2001 to December 2002.

\begin{tabular}{|c|c|c|c|c|}
\hline \multirow{2}{*}{$\begin{array}{l}\text { Sites } \\
\text { Pedra do Fogo region }\end{array}$} & \multicolumn{2}{|c|}{$\begin{array}{l}\text { Number Species } \\
\text { of hours }\end{array}$} & \multicolumn{2}{|c|}{ Male Female } \\
\hline & & & & \\
\hline $\begin{array}{l}\text { Colorida cave - internal } \\
\text { walls }\end{array}$ & 12 & - & - & - \\
\hline \multirow{3}{*}{$\begin{array}{l}\text { Colorida cave - external } \\
\text { walls }\end{array}$} & \multirow[t]{3}{*}{12} & Br. cunhai & 1 & 1 \\
\hline & & Ev. edwardsi & - & 1 \\
\hline & & Pa. lanei & 3 & - \\
\hline Armadillo borrow close to & \multirow[t]{3}{*}{1} & Br. carvalheiroi & 8 & 5 \\
\hline \multirow{2}{*}{$\begin{array}{l}\text { Colorida cave's principal } \\
\text { entrance }\end{array}$} & & Br. troglodytes & 7 & 6 \\
\hline & & Pa. pascalei & 1 & - \\
\hline Fogo cave - internal walls & 1 & - & - & - \\
\hline \multirow[t]{2}{*}{ Fogo cave - external walls } & \multirow[t]{2}{*}{1} & Pi. monticola & - & 1 \\
\hline & & Sc. sordellii & 1 & - \\
\hline \multicolumn{5}{|l|}{ Bocaina region } \\
\hline $\begin{array}{l}\text { Fendão cave - external } \\
\text { walls }\end{array}$ & 1 & - & - & - \\
\hline $\begin{array}{l}\text { Mãozinha cave - internal } \\
\text { walls }\end{array}$ & 1 & - & - & - \\
\hline $\begin{array}{l}\text { Barra Bonita cave - } \\
\text { internal walls }\end{array}$ & 1 & - & - & - \\
\hline $\begin{array}{l}\text { Minotauro cave - internal } \\
\text { walls }\end{array}$ & 1 & - & - & - \\
\hline $\begin{array}{l}\text { Paivas cave - internal } \\
\text { walls }\end{array}$ & 1 & - & - & - \\
\hline \multicolumn{5}{|l|}{ Sede region } \\
\hline Armadillo borrow in & 24 & Br. carvalheiroi & 28 & 4 \\
\hline forest surrounding the & & Br. troglodytes & 1 & - \\
\hline \multirow[t]{2}{*}{ researchers' house } & & Pi. monticola & - & 3 \\
\hline & & Pa. pascalei & 55 & 19 \\
\hline $\begin{array}{l}\text { Trunks or roots of trees, } \\
\text { fallen leaves and holes in } \\
\text { soil and rocks }\end{array}$ & 11 & - & - & - \\
\hline Total & 67 & & 105 & 40 \\
\hline
\end{tabular}

Br. = Brumptomyia $;$ Ev. = Evandromyia $;$ Pa. = Psathyromyia $;$ Pi. = Pintomyia; Sc. $=$ Sciopemyia.

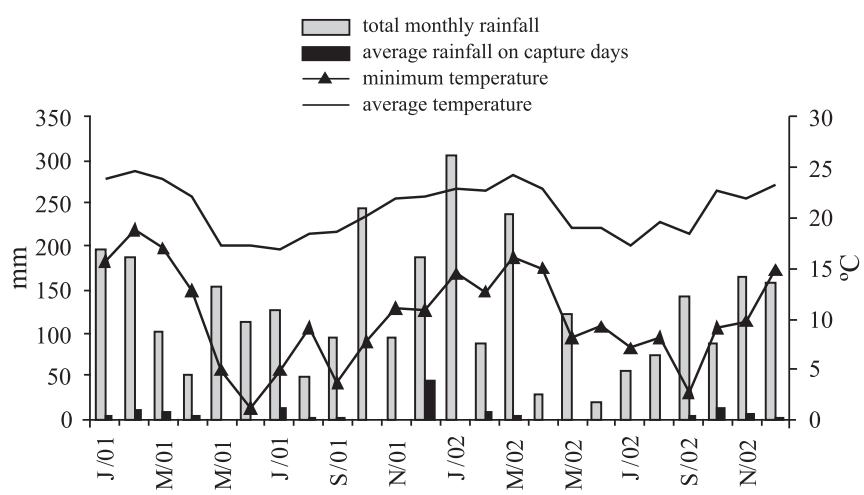

Fig. 3. Total monthly rainfall, average rainfall on capture days in the PEI (810 m a.s.l.), and minimum and average monthly temperatures in Capão Bonito municipality (900 m a.s.l.)

monthly in the armadillo burrows during 2001 and 2002 in the forest surrounding the researchers' house is presented in Table IV. The Williams' averages by season were: autumn (3.28 insects), winter (2.34 insects), summer (0.0 insects) and spring ( 0.47 insects), thus showing a clear difference between the drier and colder periods (autumn and winter) and the humid and hot ones (spring and summer). This result contrasts with that related to Br. troglodytes, the most abundant species captured with light traps in the two ecotopes where it was most numerous (domicile in the Sede and canopy in the Bocaina region).

The standardized index of species abundance (SISA) (Table V) calculated only for the species captured with automatic light traps installed in the thirteen ecotopes distributed in the three regions shows $\mathrm{Br}$. troglodytes as the most abundant species $(\mathrm{SISA}=0.703)$, followed by $\mathrm{Pa}$. lanei $(\mathrm{SISA}=0.594)$, Pi. monticola ( $\mathrm{SISA}=0.455$ ) and Brumptomyia carvalheiroi $(\mathrm{SISA}=0.434)$, in that order.

The annual rainfall in the PEI (at the meteorological station) in 2000, before the beginning of the project, was of $1,031.8 \mathrm{~mm}$, during 2001 of $1,600.7 \mathrm{~mm}$ and in 2002 of $1,488.8 \mathrm{~mm}$. The distribution of the total monthly rainfall, the average of the daily rains and the monthly mean and minimum temperatures in Capão Bonito municipality, close to the PEI, are shown in Figure 3. The driest and coldest period extends from April/May to September. Only in December 2001 did high levels of rainfall occur on capture days and in 2001 the minimum temperatures were lower than those of 2002.

\section{DISCUSSION}

During the two years of captures in the PEI, the total number of insects collected in the three areas sampled was very small. Several of the species captured, such as those of the genus Brumptomyia and Pa. pascalei which present a clear association with armadillo burrows (Aguiar \& Medeiros 2003), are known not to bite humans. For several species captured, there are evidences of their attraction to humans, Ex. firmatoi (Gomes et al. 1989), Mg. migonei, Ny. neivai and Pi. fischeri (Aguiar et al. 1989; Gomes et al. 1989), Ny. intermedia (Aguiar et al. 1987, Afonso et al. 2005, 2007), Pa. 
lanei (Gomes \& Galati, 1989), Pi. monticola (Hermeto et al. 1994; Afonso et al. 2007), Ps. ayrozai (Gomes \& Galati, 1989; Aguiar et al. 1993, Afonso et al. 2007) and Ps. geniculatus (Aguiar et al. 1993). Nonetheless, of these species, only Mg. migonei, Ny. intermedia and Ny. neivai have been implicated as vectors of Leishmania (Viannia) braziliensis Vianna, 1911, the agent of human cutaneous leishmaniasis in the Brazilian Southeast (Rangel \& Lainson 2003; Pita-Pereira et al. 2005; Andrade Filho et al. 2007). But as in the PEI they presented very low frequencies, the risk of transmission of this parasite, whether in caves or in forests, seems also to be very small.

The capture of $N y$. intermedia and Ny. neivai, this latter resuscitated from the synonymy of the former by Marcondes (1996), with allopatry, respectively on the coast and in the interior of São Paulo state, corroborates their occurrences in sympatry in the Ribeira Valley as registered by Marcondes et al. (1998) and Andrade Filho et al. (2007); however, for $N y$. intermedia this finding represents its the most western and highest limits. The presence of Ny. neivai exclusively in the Bocaina region is perhaps due to its proximity to the open area of degraded pasture, since this species predominated in anthropized areas of the interior of São Paulo (Condino et al. 1998; Odorizzi \& Galati 2007).

Pi. monticola, with the highest frequencies on the Shannon traps and captured biting the guide and researcher workers of the team, presents some probability of bothering the humans who frequent the PEI. Further, this species has been suspected of being a vector of Leishmania (Leishmania) enriettii Muniz \& Medina, 1948, a parasite of the guineapig, on the outskirts of Curitiba city in the Paraná state, and has been shown to be susceptible to experimental infection by this agent captured in the same region, but the flagellates seem to have failed to produce infection when inoculated into clean laboratory guinea-pigs (Luz et al. 1967). The infection of a guinea-pig was also identified on a farm in Capão Bonito municipality (Machado et al. 1994; Lainson 1997) situated very close to the PEI. Thus perhaps, if more females of Pi. monticola had been dissected, more information about the vector of this parasite and possibly other leishmanias would have been obtained, since only 18 of its females were dissected and in foci of cutaneous leishmaniasis the natural infection by flagellates rate is only about $0.2 \%$ (Galati et al. 1996). Some other aspects of its behaviour observed in the PEI had also been registered in other areas: attraction to light in the Rio Doce Valley in Minas Gerais state, a focus of cutaneous leishmaniasis (Hermeto et al. 1994), and in areas of Atlantic forest in Rio de Janeiro state (Afonso et al. 2007); predominance in high areas (850-950 m) in the Espírito Santo state (Ferreira et al. 2001); its capture in greater numbers in April in another fragment of Atlantic forest in Morretes, state of Paraná (Marcondes et al. 2001).

Ex. firmatoi, Pa. lanei, Pa. sp. Pi. fischeri, Ps. ayrozai and Ps. geniculatus, species with some degree of anthropophily may, despite their low frequencies, sporadically cause bother to visitors to and inhabitants of the PEI. Pa. sp., a new species close to $P a$. pestanai, was captured in small numbers biting the researchers in the PEI.

Ev. edwardsi, the sixth most abundant in the automatic
Table IV. Phlebotomines captured in armadillo burrows situated in the surroundings of Sede of the PEI, by species, sex and season of 2001 and 2002.

\begin{tabular}{|c|c|c|c|c|c|c|c|c|c|c|c|}
\hline \multirow[t]{2}{*}{$\begin{array}{l}\text { Species } \\
\text { Season/year }\end{array}$} & \multicolumn{2}{|c|}{$\begin{array}{c}\text { Brumpto- } \\
\text { myia } \\
\text { carva- } \\
\text { lheiroi }\end{array}$} & \multicolumn{2}{|c|}{$\begin{array}{l}\text { Brump- } \\
\text { tomyia } \\
\text { troglo- } \\
\text { dytes }\end{array}$} & \multicolumn{2}{|c|}{$\begin{array}{l}\text { Pinto- } \\
\text { myia } \\
\text { monti- } \\
\text { cola }\end{array}$} & \multicolumn{2}{|c|}{$\begin{array}{l}\text { Psathy- } \\
\text { romyia } \\
\text { pascalei }\end{array}$} & \multicolumn{3}{|c|}{ Total } \\
\hline & $\mathrm{M}$ & $\mathrm{F}$ & $\mathrm{M}$ & $\mathrm{F}$ & M & $\mathrm{F}$ & $\mathrm{M}$ & $\mathrm{F}$ & $M$ & $\mathrm{~F}$ & $\mathrm{~T}$ \\
\hline \multicolumn{12}{|l|}{2001} \\
\hline Summer & - & - & - & - & - & - & - & - & - & - & - \\
\hline Autumn & 15 & 1 & - & - & - & 1 & 17 & 8 & 32 & 10 & 42 \\
\hline Winter & 9 & 2 & - & - & - & 2 & 22 & 9 & 31 & 13 & 44 \\
\hline Spring & - & - & - & - & - & - & - & - & - & - & - \\
\hline $\begin{array}{l}\text { Subtotal } \\
2002\end{array}$ & 24 & 3 & - & - & - & 3 & 39 & 17 & 63 & 23 & 86 \\
\hline Summer & - & - & - & - & - & - & - & - & - & - & - \\
\hline Autumn & - & - & - & - & - & - & 5 & 2 & 5 & 2 & 7 \\
\hline Winter & - & - & 1 & - & & - & 11 & - & 12 & - & 12 \\
\hline Spring & 4 & 1 & - & - & - & - & - & - & - & - & - \\
\hline Subtotal & 4 & 1 & 1 & - & - & - & 16 & 2 & 21 & 3 & 24 \\
\hline Total & 28 & 4 & 1 & - & - & 3 & 55 & 19 & 84 & 26 & 110 \\
\hline
\end{tabular}

light trap captures, the second with Shannon traps and the most frequently captured in areas associated with the caves of the Pedra do Fogo Region, has often been captured in Atlantic forest areas. It has been found to be naturally infected by $L e$. braziliensis in Cotia municipality, in the metropolitan region of Greater São Paulo, in a focus of visceral canine leishmaniasis and human cutaneous leishmaniasis (Sucen 2005).

Br. troglodytes was the most abundant species captured with automatic light traps in the PEI (the anthropic environments included), differently from other areas of the Ribeira Valley (Gomes \& Galati 1989; Gomes et al. 1990; Domingos et al. 1998). As the activity of the species of Brumptomyia is essentially in forests and closely associated with armadillo burrows (Aguiar \& Medeiros 2003), the predominance of this species in the forested areas is to be expected, though not in an anthropic environment, such as was the veranda of the domicile and peridomicile of the Sede. Probably the dominance of Brumptomyia in the domicile and peridomicile of this region may be attributed to the attraction of the lights and to the fact that in the cold, dry season, the armadillo females breast-feed their young in their burrows. Hence, a greater number of sandflies were aspirated in this period. At the beginning of the hot and humid season, the armadillos together with their young abandon their burrows to look for food. The humid area with very dense undergrowth, situated around the domicile sampled (Sede region), provided a favorable environment for this purpose and armadillo tracks are very common there. Thus are the highest frequencies of this group of phlebotomines in the domicile and peridomicile in more humid and hotter periods to be explained. On the other hand, $\mathrm{Pa}$. pascalei, which predominated in armadillo burrows, is probably less attracted to light, as may be deduced by the small numbers of specimens captured with the automatic light traps.

The armadillo Dasypus novemcinctus has been identified as the wild host of Leishmania (Viannia) naiffi Lainson \& Shaw, 1989 in the Brazilian states of Pará and Amazonas, and 
Table V. Index of Species Abundance (ISA) and Standardised Index of Species Abundance (SISA) of phlebotomines captured monthly with automatic light traps at 13 ecotopes in the PEI, from January 2001 to December 2002.

\begin{tabular}{lccc}
\hline Species & ISA & SISA & Position \\
\hline Br. bragai & 11.385 & 0.056 & 15th \\
Br. carvalheiroi & 7.231 & 0.434 & 4th \\
Br. cunhai & 9.077 & 0.266 & 7 th \\
Br. troglodytes & 4.269 & 0.703 & 1 st \\
Ev. correalimai & 11.769 & 0.021 & 18 th \\
Ev. edwardsi & 8.115 & 0.353 & 6th \\
Ex. firmatoi & 10.385 & 0.147 & 11th \\
Mg. rabelloi & 11.423 & 0.052 & 16th \\
Mi. petari & 9.243 & 0.251 & 8th \\
Ny. intermedia & 10,192 & 0.164 & 10th \\
Ny. neivai & 10.038 & 0.178 & 9th \\
Pa. lanei & 5.462 & 0.594 & 2nd \\
Pa. pascalei & 7.808 & 0.381 & 5th \\
Pa. sp. & 10.885 & 0.101 & 12th \\
Pi. fischeri & 11.269 & 0.066 & 15th \\
Pi. monticola & 7.000 & 0.455 & 3rd \\
Ps. ayrozai & 11.615 & 0.035 & 17th \\
Ps. geniculatus & 11.115 & 0.080 & 13th \\
Sc. microps & 11.269 & 0.066 & 14th \\
\hline
\end{tabular}

Br. = Brumptomyia; Ev. = Evandromyia; Ex. = Expapillata $M g .=$ Migonemyia; Mi. = Micropygomyia; Ny. =Nyssomyia; Pa. = Psathyromyia; Pi. = Pintomyia Ps. = Psychodopygus; Sc. = Sciopemyia.

in French Guyana, and Ps. ayrozai has been suspected as the vector, mainly among populations of this mammal. However, thus far this parasite has not been found in the Brazilian Southeastern Region where cutaneous leishmaniasis cases have mainly been associated with Le. braziliensis (Lainson $\&$ Shaw 2005). Thus, infection by this parasite and possibly others in armadillos calls for further investigation, as well as that in the sandflies associated with their burrows, since it is they which may maintain the natural enzootic foci.

Despite the large number of Brazilian speleological provinces (Auler 2000), very few studies of their phlebotomine fauna exist. Of the species cited by the CIPA group (1999), none was found in the PEI. Comparing the fauna of the PEI with that of the calcareous speleological province of the Serra da Bodoquena (Galati et al. 2003) in the Brazilian Mid-West, where savannah is the predominant vegetation (Galati et al. 2006), only the species Brumptomyia cunhai and Sc. sordellii are common to both areas. Though inhabited by distinctspecies, both provinces share some common groups: Evandromyia: cortelezzii series, Pintomyia (Pintomyia), Micropygomyia (Sauromyia), Nyssomyia, Psathyromyia (Forattiniella) and Psathyromyia (Psathyromyia), shannoni series. However, no species of the dominant Lutzomyia (Lutzomyia) group present in the caves or forests of the Serra da Bodoquena was found in the PEI as, for example, Lu. almerioi Galati \& Nunes 1999, an anthropophilic, troglophilic species of high density, and probable vector of agents of cutaneous and visceral leishmaniases (Savani et al. 2009).

As regards the forest sandfly fauna of the Bodoquena, neither Nyssomyia whitmani (Antunes \& Coutinho, 1939), one of the main vectors of Le. braziliensis, the most widespread Brazilian agent of cutaneous leishmaniasis, nor Lutzomyia longipalpis, the main vector of Leishmania (Leishmania) infantum chagasi Cunha \& Chagas, 1937, the two most abundant species on the Serra da Bodoquena, was found in the PEI. However, two species of Nyssomyia, Ny. intermedia and $N y$. neivai, also considered to be vectors of cutaneous leishmaniasis, were captured in the PEI, but their density was very low.

Another clear difference observed between these two provinces is the very low density of phlebotomines in caves of the PEI, as well as in their surrounding forests. Thus it seems that the risk of transmission of leishmaniasis in the PEI is very small, if any.

It is possible that the greater altitude, lower temperatures and higher relative humidity of the PEI do not afford an adequate environment for the development of the immature stages of the phlebotomines and that the microhabitat represented by the armadillo burrow, being more appropriate for the sandfly, probably explains the predominance of Brumptomyia spp and Pa. pascalei, closely associated with this mammal (Aguiar \& Medeiros 2003).

Of the few specimens (40 insects/72 samples) representing the 10 species captured in caves: Br. carvalheiroi, Ev. edwardsi, Ex. firmatoi, Mi. petari, Ny. intermedia, Ny. neivai, Pi. monticola, Pa. lanei, Pa. pascalei and Sc. microps none seems to present any high degree of cave dependency, since all the species have been captured in environments without caves. Some of these species use these ecotopes as resting sites. However, Ev. edwardsi, Sc. microps and Mi. petari may also have their breeding places in caves, because beyond having been captured in this project exclusively (or in the highest frequencies) in caves or on the external walls of the Colorida cave, they belong to groups found in close association with the caves of the karst Corumbá formation in the Brazilian Mid-West region (Galati et al. 1997, 2003) and some of their populations may therefore be identified as troglophiles. Though there is no information as to the occurrence of Ex. firmatoi in other caves, in the PEI it was captured exclusively in the Colorida cave, on its external walls or on the Shannon traps in front of it. So it is possible that it is also a troglophile.

Acknowledgements. The authors wish to express their thanks to the guide, Aparício Paiva, who helped us to make the captures. As also to Dr. Ademir Galati who provided the necessary logistic support. Thanks are also due to Mr. Arthur Anthony Boorne for his correction of the English text. Financial support: FAPESP (00/06811-0). IBAMA-SP licence (process $\mathrm{n}$. 02027007000/2000-76).

\section{REFERENCES}

Afonso, M. M. S; A. C. Gomes; C. R. V. Meneses \& E. F. Rangel. 2005. Studies on the feeding habits of Lutzomyia $(N$.) intermedia (Diptera, Psychodidae) vector of cutaneous leishmaniasis in Brazil. Cadernos de Saúde Pública 21: 1816-1820.

Afonso, M. M. S.; W. A. Costa; A. C. R. Azevedo; S. M. Costa; M. L. Vilela \& E. F. Rangel. 2007. Data on sandfly fauna (Diptera, Psychodidae, Phlebotominae) in Itatiaia, National Park, Rio de Janeiro state, Brazil. Cadernos de Saúde Pública 23: 725-730.

Aguiar, G. M. \& W. M. Medeiros. 2003. Distribuição regional e hábitats das 
espécies de flebotomíneos do Brasil, p. 207-255. In: E. F. Rangel \& R. Lainson (orgs.). Flebotomíneos do Brasil, Rio de Janeiro, Fiocruz, $367 \mathrm{p}$.

Aguiar, G. M.; M. L. Vilela \& R. B. Lima. 1987. Ecology of the sandflies of Itaguaí, an area of cutaneous leishmaniasis in the state of Rio de Janeiro. Food preferences (Diptera, Psychodidae, Phlebotominae). Memórias do Instituto Oswaldo Cruz 82: 583-584

Aguiar, G. M.; M. L. Vilela \& V. A. Ferreira \& T. G. Santos. 1989. Ecologia dos flebótomos em um recente foco ativo de leishmaniose tegumentar no norte do Estado do Paraná (Diptera, Psychodidae, Phlebotominae). Memórias do Instituto Oswaldo Cruz 84 (supl. IV): 7-8.

Aguiar, G. M.; V. M. Medeiros; T. G. Santos; A. F. L. Klein \& V. A. Ferreira. 1993. Ecology of sandflies in a recent focus of cutaneous leishmaniasis in Paraty, litoral of Rio de Janeiro state (Diptera, Psychodidae, Phlebotominae). Memórias do Instituto Oswaldo Cruz 88: 339-340.

Andrade- Filho, J. D.; A. C. L. Silva \& A. L. Falcão. 2001. Phlebotomine sandflies in the State of Piauí, Brazil (Diptera: Psychodidae: Phlebotominae). Memórias do Instituto Oswaldo Cruz 96: 10851087.

Andrade-Filho, J. D.; E. A. B. Galati \& A. L. Falcão. 2007. Nyssomyia intermedia (Lutz \& Neiva, 1912) and Nyssomyia neivai (Pinto, 1926) (Diptera: Psychodidae: Phlebotominae) geographical distribution and epidemiological importance. Memórias do Instituto Oswaldo Cruz 102: 481-487.

Auler, A. S. 2002. Karst areas in Brazil and the potential for major caves on overview. Boletin de la Sociedad Venezolana de Espeleología 36: 29-35.

Carvalho, M. P.; C. H. G. Cezare; C. G. Costa; R. G. T. Cunha; S. S. Dornelles; M. S. Fialho; J. C. Guix; A. Hernándes; P. C. Lazarin; L. Lorens; M. Martín; E. Mateos; C. Miquel; L. M. Petroni; B. S. Pinto; K. Pisciotta; C. Sanches; I. Oliveras \& A. Serra. 2002. Description of the study area, p. 27-50. In: E. Meteos, J. C. Guix; A. Serra; K. Pisciotta (eds.) Censuses of Vertebrates in a Brazilian Atlantic Rainforest Area: the Paranapiacaba Fragment. Barcelona. Centre de Recursos de Biodiversitat Animal, Diviso III, Universitat de Barcelona, 217 p.

CIIAGRO (Centro Integrado de Informações Agrometeorológicas). 2007. Resenha Agrometeorológica. Boletim Mensal < http://www.ciiagro.sp. gov> (accessed in 05/09/2007).

CIPA Group 1999. Computer-aided Identification of Phlebotomine Sandflies of America. <http://cipa.snv.jussieu.fr > (accessed in 12/09/2007).

Condino, M. L. F.; S. M. P. Sampaio; L. F. Henriques; E. A. B. Galati; D. M. V. Wanderley \& F. M. A. 1998. Corrêa. Leishmaniose tegumentar americana: flebotomíneos de área de transmissão no município de Teodoro Sampaio, região sudoeste do Estado de São Paulo, Brasil. Revista da Sociedade de Medicina Tropical 31: $355-360$.

CVE (Centro de Vigilância Epidemiológica Alexandre Vranjac, Secretaria de Estado da Saúde de São Paulo). 2007. Leishmaniose Tegumentar Americana < http://www.cve.saude.sp.gov.br/htm/zoo/lta_reg.htm> (accessed in 10/09/2007).

Desjeux, P. 2004. Leishmaniasis: current situation and new perspectives. Comparative Immunology, Microbiology \& Infectious Diseases 27:305-318.

Domingos, M. F.; G. C. Carreri-Bruno; R. M. C. Ciaravolo; E. A. B. Galati; D. M. V. Wanderley \& F. M. A. Corrêa. 1998. Leishmaniose tegumentar americana: flebotomíneos de área de transmissão, no município de Pedro de Toledo, região sul do Estado de São Paulo. Revista da Sociedade Brasileira de Medicina Tropical 31: 425-432.

Ferreira, A. L.; P. A. Sessa; J. B. Varejão \& A. Falqueto. 2001. Distribution of sandflies (Diptera: Psychodidae) at different altitudes in an endemic region of American Cutaneous Leishmaniasis in the state of Espírito Santo, Brazil. Memórias do Instituto Oswaldo Cruz 96: 1061-1067.

Forattini, O. P. 1973. Entomologia Médica. Phlebotominae.Leishmanioses. Bartonelose. São Paulo, Edgard Blücher Ltda, 658 p.

Forattini, O. P.; E. X. Rabello; O. P. Serra; M. D. Cotrim; E. A. B. Galati \& J. M. S. Barata. 1976. Observações sobre a transmissão da leishmaniose tegumentar no Estado de São Paulo, Brasil. Revista de Saúde Pública 10: $31-43$.

Galati, E. A. B. 2003. Morfologia, terminologia de adultos e identificação dos táxons da América, p. 53 -175. In E. F. Rangel \& R. Lainson (orgs.). Flebotomíneos do Brasil. Rio de Janeiro, Fiocruz, 367 p.

Galati, E. A. B.; V. L. B. Nunes; M. E. C. Dorval; E. T. Oshiro; G. Cristaldo; H. C. Rocha \& W. R. Garcia. 1996. Estudo dos flebotomíneos (Diptera,
Psychodidae), em área de leishmaniose tegumentar no Estado de Mato Grosso do Sul, Brasil. Revista de Saúde Pública 30: 115 -128.

Galati, E. A. B.; V. L. B. Nunes; F. A. Rego-Jr; E. T. Oshiro \& M. Rodrigues. 1997. Estudo de flebotomíneos (Diptera, Psychodidae) em foco de leishmaniose visceral no Estado de Mato Grosso do Sul, Brasil. Revista de Saúde Pública 31: 378-390.

Galati, E. A. B.; V. L. B. Nunes; M. E. D. Dorval; G. Cristaldo; H. C. Rocha; R. M. Gonçalves-Andrade \& G. Naufel. 2001. Attractiveness of black Shannon trap for phlebotomines. Memórias do Instituto Oswaldo Cruz 96: 641-647.

Galati, E. A. B.; V. L. B. Nunes; P. C. Boggiani; M. E. C. Dorval; G. Cristaldo; H. C. Rocha; E. T. Oshiro; R. M. Gonçalves-Andrade \& G. Naufel. 2003. Phlebotomine (Diptera, Psychodidae) in caves of the Serra da Bodoquena, Mato Grosso do Sul state, Brazil. Revista Brasileira de Entomologia 47: 283-296.

Galati, E. A. B.; V. L. B. Nunes; P. C. Boggiani; M. E. Dorval; G. Cristaldo; H. C. Rocha \& G. A. Damasceno-Junior. 2006. Phlebotomines (Diptera: Psychodidae) in forested areas of the Serra da Bodoquena, state of Mato Grosso do Sul, Brazil. Memórias do Instituto Oswaldo Cruz 101: 175-193.

Gnaspini-Netto, P. \& E. Trajano. 1992. Província Espeleológica do Vale do Ribeira, região da Fazenda Intervales, SP: exploração, topográfica e biologia. Espeleo-Tema 16: 41-74.

Gomes, A. C. \& E. A. B. Galati. 1987. Aspectos ecológicos da leishmaniose tegumentar americana. 5. Estratificação da atividade espacial e estacional de Phlebotominae (Diptera, Psychodidae) em áreas de cultura agrícola da região do Vale do Ribeira, Estado de São Paulo, Brasil. Memórias do Instituto Oswaldo Cruz 82: 467-473.

Gomes, A. C. \& E. A. B. Galati. 1989. Aspectos ecológicos da leishmaniose tegumentar americana. 7. Capacidade vetorial flebotomínea em ambiente florestal primário do Sistema da Serra do Mar, região do Vale do Ribeira, Estado de São Paulo Revista de Saúde Pública 23: 136-142.

Gomes, A. C.; J. M. S. Barata; E. O. R. Silva \& E. A. B. Galati. 1989. Aspectos ecológicos da leishmaniose tegumentar americana. 6. Fauna flebotomínea de matas residuais situadas na região centro-nordeste do Estado de São Paulo, Brasil. Revista do Instituto de Medicina Tropical de São Paulo 31: 32-39.

Gomes, A. C.; E. X. Rabello; J. L. Santos \& E. A. B. Galati. 1980. Aspectos ecológicos da leishmaniose tegumentar americana. I. Estudo experimental da freqüência de flebotomíneos a ecótopos artificiais com referência especial a Psychodopygus intermedius. Revista de Saúde Pública 14: 540-556.

Gomes, A. C.; E. X. Rabello; J. L. Santos \& E. A. B. Galati. 1982. Aspectos ecológicos da leishmaniose tegumentar americana. 2. Ecótopo artificial como abrigo de Psychodopygus intermedius e observações sobre a alimentação e reprodução sob influência de fatores físicos naturais. Revista de Saúde Pública 16: 149-159.

Gomes, A. C; E. X. Rabello; J. L. Santos \& E. A. B. Galati. 1983. Aspectos ecológicos da leishmaniose tegumentar americana. 3. Observações naturais sobre o ritmo diário da atividade de Psychodopygus intermedius em ambiente extraflorestal. Revista de Saúde Pública 17: 23-30.

Gomes, A. C.; J. L. Santos \& E. A. B. Galati. 1986. Ecological aspects of American cutaneous leishmaniasis 4. Observations on the endophilic behavior of the sandfly and the vectorial role of Psychodopygus intermedius in the Ribeira Valley region of the São Paulo state. Revista de Saúde Pública 20: 280-287.

Gomes, A. C.; S. G. Coutinho; G. V. Paim; S. M. O. Oliveira; E. A. B. Galati; M. P. Nunes; N. A. Capinzaiki; Y. I. Yamamoto \& P. Rotter 1990. Aspectos ecológicos da leishmaniose tegumentar americana. 8. Avaliação da atividade enzoótica de Leishmania (Viannia) braziliensis, em ambiente florestal e peridomiciliar, Região do Vale do Ribeira, Estado de São Paulo, Brasil. Revista do Instituto de Medicina Tropical de São Paulo 32: 105-115.

Haddow, A. J. 1960. Studies on the biting-habits and medical importance of East African mosquitoes in the genus Aedes. I. Subgenera Aedimorphus, Banksinella and Nunnius. Bulletin of Entomological Research 50: 759 -779 .

Hayek, L. A. C. \& M. A. Buzas. 1997. Surveying Natural Populations. New York, Columbia University Press, 563 p.

Hermeto, M. V.; D. V. Dias; O. Genaro; A. Rotondo-Silva; C. A. Costa; V. P. C. P. Toledo; M. S. M. Michalick; P. Williams \& W. Mayrink. 1994 Outbreak of cutaneous leishmaniasis in the Rio Doce Valley, Minas 
Gerais, Brazil. Memórias do Instituto Oswaldo Cruz 89: 519 -521.

Karmann, I. \& J. A. Ferrari. 2002. Carste e Cavernas do Parque Estadual Turístico do Alto Ribeira (PETAR), SP - Sistemas de cavernas com paisagens subterrâneas únicas. p. 401-413. In: C. Schobbenhaus; D. A Campos; E. T. Queiroz; M. Winge \& M. L. C. Berbert-Born (Eds.) Sítios Geológicos e Paleontológicos do Brasil. Brasília, DNPM/CPRM - Comissão Brasileira de Sítios Geológicos e Paleobiológicos (SIGEP), $554 \mathrm{p}$.

Köppen, W. 1948. Climatologia: com um estúdio de los climas da tierra. México, Fondo de Cultura Economica, 478 p.

Lainson, R. 1997. On Leishmania enriettii and other enigmatic Leishmania species of the Neotropics. Memórias do Instituto Oswaldo Cruz 92: 377-387.

Lainson, R. \& J. J. Shaw. 2005. New World leishmaniasis, p. 313-349. In: F. E. G. Cox; J. P. Kreier \& D. Wakelin (eds.). Topley \& Wilson's Microbiology and Microbial Infections, Parasitology. $10^{\text {th }}$ ed. London, Arnold, 883 p.

Luz, E.; M. Giovannoni \& A. M. Borba. 1967. Infecção de Lutzomyia monticola por Leishmania enriettii. Anais da Faculdade de Medicina da Universidade Federal do Paraná 9/10: 121-128.

Machado, M. I.; R. V. Milder; R. S. Pacheco; R. R. Braga \& R. Lainson. 1994. Naturally acquired infections with Leishmania enriettii Muniz and Medina 1948 in guinea-pigs from São Paulo, Brazil. Parasitology 109: 135-138.

Marcondes, C. B. 1996. A redescription of Lutzomyia (Nyssomyia) intermedia (Lutz \& Neiva, 1912), and resurrection of L. neivai (Pinto, 1926) (Diptera, Psychodidae, Phlebotominae). Memórias do Instituto Oswaldo Cruz 91: 457-462.

Marcondes, C. B. 2007. A proposal of generic and subgeneric abbreviations for phlebotomine sandflies (Diptera: Psychodidae: Phlebotominae) of the world. Entomological News 118: $351-356$.

Marcondes, C. B.; A. L. Lozovei \& J. H. Vilela. 1998. Distribuição geográfica de flebotomíneos do complexo Lutzomyia intermedia (Lutz \& Neiva, 1912) (Diptera, Psychodidae). Revista da Sociedade Brasileira de Medicina Tropical 31: 51-58.

Marcondes, C. B.; L. G. Santos-Neto \& A. L. Lozovei. 2001. Ecology of phlebotomine sandflies in Brazilian Atlantic forest. Revista da Sociedade Brasileira de Medicina Tropical 34: 255-260.

Morellato, L. P.C.; D. C. Talora; A. Takahasi; C. C. Bencke; E. C. Romera \& V. B. Ziparro. 2000. Phenology of Atlantic rain forest trees: a comparative study. Biotropica 32: 811-823.

Natal, D.; D. Marucci; I. M. Reis \& E. A. B. Galati. 1991. Modificação da armadilha CDC com testes para coletas de flebotomíneos (Diptera). Revista Brasileira de Entomologia 35: 697-700.

Odorizzi, R. M. F. N. \& E. A. B. Galati. 2007. Flebotomíneos da várzea do rio Aguapeí, região noroeste do estado de São Paulo, Brasil. Revista de Saúde Pública 41: 645-652.
Pinto da Rocha, R. 1994. Invertebrados cavernícolas da porção meridional da Província Espeleológica do Vale do Ribeira, sul do Brasil. Revista Brasileira de Zoologia 10: 229-255.

Pita-Pereira, D.; C. R. Alves; M. B. Souza; R. P. Brazil; A. L. Bertho; A. F. Barbosa \& C. C. Britto. 2005. Identification of naturally infected Lutzomyia intermedia and Lutzomyia migonei with Leishmania (Viannia) braziliensis in Rio de Janeiro (Brazil) revealed by PCR multiplex nonisotopic hybridization assay. Transactions of the Royal Society of Tropical Medicine and Hygiene 99: 905 -913.

Rangel, E. F. \& R. Lainson. 2003. Ecologia das leishmanioses: transmissores de leishmaniose tegumentar americana, p. 291-309. In: E. F. Rangel \& R. Lainson (orgs.). Flebotomíneos do Brasil. Rio de Janeiro, Fiocruz, $367 \mathrm{p}$.

Roberts, D. R. \& B. P. Hsi. 1979. An index of species abundance for use with mosquito surveillance data. Environmental Entomology 8: 10071013.

São Paulo. 2008. Projeto de desenvolvimento do ecoturismo na região da mata Atlântica (BR-L1013). Informe Ambiental. São Paulo: Governo do Estado, Secretaria do Meio Ambiente, Unidade de Coordenação do Projeto de Desenvolvimento do ecoturismo na Região da Mata Atlântica no Estado de São Paulo 69 p. http://www.ekosbrasil.org/anexos/ Informe Ambiental revisao 2008.pdf (accessed in 17/07/2009).

Savani, E. S. M.; V. L. B. Nunes; E. A. B. Galati; T. M. Castilho; R. A. Zampieri \& L. M. Floeter-Winter. 2009. The finding of Lutzomyia almerioi and Lutzomyia longipalpis naturally infected by Leishmania spp. In a cutaneous and canine visceral leishmaniases focus in Serra da Bodoquena, Brazil. Veterinary Parasitology 160: 18-24.

SIGRH. 2007 (Sistema de Informações para Gerenciamento de Recursos Hídricos do Estado de São Paulo) http://www.sigrh.sp.gov.br/cgi-bin/ bdhm.exe/procura (accessed in 05/07/2007).

SUCEN. 2005. Encontro de Lutzomyia edwardsi infectada na região da Grande São Paulo. Revista de Saúde Pública 39: 137-138.

Taniguchi, H. H.; J. E. Tolezano; R. Larosa; R. C. Elias \& E. A. B. Galati. 2002. Observações ecológicas de flebotomíneos em área endêmica de leishmaniose tegumentar americana (LTA) no município de Eldorado, Vale do Ribeira, Estado de São Paulo, Brasil, 1996-1997. Sazonalidade e freqüência de $L$. ayrozai em diferentes ecótopos com animais sentinelas em ambiente florestado. Revista do Instituto Adolfo Lutz 61: $103-112$

Trajano, E. 1984. Ecologia de populações de morcegos cavernícolas em uma região cárstica do Sudeste do Brasil. Revista Brasileira de Zoologia 2: $255-320$.

Trajano, E. 2000. Cave faunas in the Atlantic tropical rain Forest: composition ecology, and conservation. Biotropica 32: 882-893.

Young, D. G. \& M. A. Duncan. 1994. Guide to the identification and geographical distribution of Lutzomyia sandflies in Mexico, the West Indies, Central and South America (Diptera: Psychodidae). Memoirs of the American Entomological Institute 54: 1-881. 